\title{
Mateusz Hałka
}

Uniwersytet Marii Curie-Skłodowskiej w Lublinie

e-mail: mateusz.halka@poczta.umcs.lublin.pl

\section{RYNEK ENERGII ELEKTRYCZNEJ W POLSCE W LATACH 2008-2017 - ANALIZA I PERSPEKTYWY ROZWOJU}

\section{ELECTRIC ENERGY MARKET IN POLAND IN YEARS 2008-2017 - ANALYSIS AND GROWTH PROSPECTS}

DOI: $10.15611 /$ pn.2018.509.07

JEL Classification: K32, L94

Streszczenie: Celem artykułu jest przedstawienie stanu polskiej energetyki w latach 2008-2017 oraz perspektyw rozwoju, skupione na wybranych jej aspektach. Analizie poddano potencjał mocy wytwórczych i strukturę elektrowni w omawianych latach. Potwierdzony został spadek znaczenia paliw kopalnych oraz zwiększenie produkcji energii ze źródeł odnawialnych. Zaprezentowano zużycie energii w odniesieniu do grup jej konsumentów, zwłaszcza gospodarstw domowych. Badanie oparte zostało na zestawieniach liczbowych w latach, w wartościach bezwzględnych i względnych (procentowych: zmiany wartości rok do roku oraz porównanie wielkości pierwszego i ostatniego roku analizy). Ponadto przedstawione zostały elementy krajowej i międzynarodowej polityki energetycznej dla Polski oraz działania zmierzające do osiągnięcia zakładanych celów w przyszłości. W opracowaniu wykorzystano krajowe oraz międzynarodowe raporty nt. rynku energetycznego w Polsce, dane GUS i BDL, strategie krajowe i międzynarodowe oraz literaturę przedmiotu.

Slowa kluczowe: rynek energii w Polsce, konsumpcja energii elektrycznej.

Summary: The main aim of this paper is to present an overview of Polish energy market in years 2008-2017 and its development perspectives, first of all energy consumption. For the purpose of this article, selected aspects of the energy market were chosen and they were compared over the years. Based on data, conclusions were created and they were comprared with the government and internacional strategies of the Polish electric market growth prospects.

Keywords: electric energy market in Poland, energy consumption. 


\section{Wstęp}

Zużycie energii elektrycznej jest jedną z miar cywilizacyjnego rozwoju kraju. Im jest ono wyższe, tym kraj jest uznawany za bardziej rozwinięty. Dane historyczne potwierdzają, że w ciągu ostatniego stulecia wzrost ekonomiczny i rozwój cywilizacyjny zawsze były związane ze zwiększoną konsumpcją energii elektrycznej. Przykładowo w pierwszej połowie XIX w. zużycie energii elektrycznej w Wielkiej Brytanii (ówczesne centrum rewolucji przemysłowej) wzrosło czterokrotnie. Według analiz przewidywane są dalsze wzrosty. Prognozy Międzynarodowej Agencji Energetycznej wskazują, że w latach 2005-2030 zapotrzebowanie na energię elektryczną wzrośnie o 55\%. Głównymi ośrodkami wzrostu mają być kraje Afryki Centralnej oraz Azji Południowo-Wschodniej. Z danych agencji wynika, że za 70\% wzrostu konsumpcji energii odpowiadać będą Indie i Chiny. Szacunki dowodzą, że obecnie tylko w Afryce ok. 600 mln ludzi jest pozbawionych dostępu do energii elektrycznej. Przewidywana elektryfikacja wszystkich gospodarstw domowych na całym świecie ma zakończyć się ok. 2080 r. Potencjał rozwoju jest jeszcze bardziej widoczny, gdy porównane zostanie zużycie energii elektrycznej per capita. Przykładowo w USA (jeden z krajów o najwyższym zużyciu energii na mieszkańca) zapotrzebowanie na energię jest 800 razy wyższe niż w krajach rozwijających się i tylko dwukrotnie wyższe niż w krajach Europy Zachodniej [Internacional Energy Agency 2014].

W skali Polski zużycie energii elektrycznej jest również ciekawym tematem. Badając sytuację energii elektrycznej w ostatnich latach i perspektywy rozwoju, w kraju następuje zmiana zarówno ilościowa, jak i jakościowa. Obserwowany jest wzrost zużycia energii wynikający z ciągłego rozwoju i modernizacji gospodarki. Należy zwrócić uwagę na coraz bardziej zróżnicowaną strukturę energii, która nastawiona jest na zmniejszanie znaczenia paliw kopalnych na rzecz np. odnawialnych źródeł energii [GUS 2017a].

Celem artykułu jest przedstawienie charakterystyki oraz zmian w polskiej energetyce w latach 2008-2017, a także ukazanie perspektyw jej rozwoju. Analiza kładzie nacisk na wybrane wskaźniki opisujące branżę energetyczną, m.in. uwarunkowania konsumpcji energii. Do opracowania została wykorzystana literatura przedmiotu oraz polskie i międzynarodowe raporty obrazujące rynek energii, dane z instytucji publicznych (np. GUS, BDL) oraz rządowe strategie i prognozy dotyczące omawianego sektora.

\section{Rynek energii elektrycznej w Polsce}

Rynek energii elektrycznej można definiować jako rynek, w którym przedmiotem handlu jest energia elektryczna. Działa on na dwóch poziomach [Mielczarski 2000]: rynek hurtowy, w którym uczestniczą producenci energii oraz nabywcy hurtowi; oraz rynek detaliczny, w którym producenci energii dostarczają odbiorcom energię 
elektryczną, konkurując ceną, warunkami dostawy oraz usługami dodatkowymi. Uczestnikami polskiego rynku energii elektrycznej są: wytwórcy energii, dystrybutorzy energii, spółki obrotu energią oraz podmioty, których zadaniem jest przesyłanie energii elektrycznej. Wszyscy uczestnicy są zobowiązani do działania opartego na przepisach ustawy Prawo energetyczne, natomiast instytucją, która reguluje prawne aspekty działania rynku, jest Urząd Regulacji Energetyki [Ustawa z 10 kwietnia 1997].

Polski rynek energii elektrycznej oferuje prawo wyboru dystrybutora energii. Możliwość taka pojawiła się na skutek liberalizacji rynku, która nastąpiła 1 lipca 2004 r. dla klientów instytucjonalnych oraz 1 lipca 2007 r. dla odbiorców indywidualnych (odbiorcy taryf $\mathrm{G}^{\mathrm{l}}$ ). W praktyce jednak zmiana sprzedawcy energii możliwa jest dwukrotnie w roku i tylko spośród dystrybutorów prowadzących działalność na danym obszarze. Rok 2008 był więc pierwszym pełnym rokiem trwania wolnego rynku, co było motywacją wyboru czasu niniejszego opracowania [Ustawa z 10 kwietnia 1997].

Na polskim rynku energii elektrycznej działa 5 dystrybutorów: Energa, ENEA, Tauron, Polska Grupa Energetyczna (PGE) oraz Innogy Stoen Operator (operator energii na obszarze Warszawy). Ich procentowy udział w rynku przedstawia się następująco:

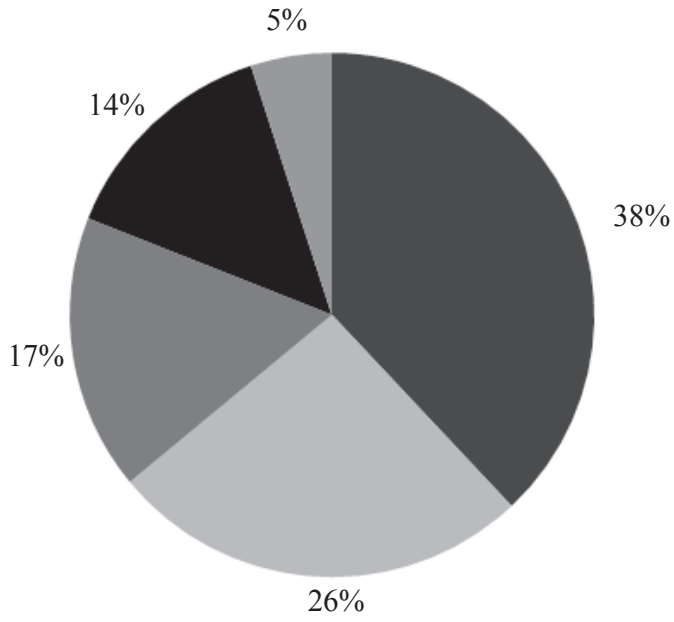

- Tauron $\square$ PGE $\quad$ Energa ENEA $\square$ Innogy Stoen Operator

Rys. 1. Procentowy udział dystrybutorów na polskim rynku energii elektrycznej w 2016 r.

Źródło: opracowanie własne na podstawie danych GUS.

1 Taryfy G (G11, G12, G12w) są przeznaczone dla odbiorców indywidualnych (gospodarstw domowych). 
Na podstawie rysunku 1. można zauważyć, że dominującą pozycję na polskim rynku energii elektrycznej ma spółka Tauron. Obszar jej działania obejmuje 57 tys. $\mathrm{km}^{2}$, głównie w południowej części Polski, ma 5,4 mln zakontraktowanych odbiorców. Drugie miejsce, z udziałem mniejszym o 12 p.p. od lidera, jest PGE, która dostarcza energię na obszarze środkowo-wschodniej Polski. Kolejna w klasyfikacji jest Energa, której udział w rynku wynosi 17\%, co przekłada się na 2,9 mln odbiorców. Spółka ta działa na północy Polski. Na zachodzie operuje następna w klasyfikacji ENEA. Jej udział w rynku to $14 \%$, co odpowiada 2,5 mln odbiorców. Ostatni w zestawieniu, Innogy Stoen Operator, działa na obszarze Warszawy i okolic, obsługując niespełna $1 \mathrm{mln}$ klientów [Enerad.pl 2018].

W Polsce energię elektryczną produkują głównie elektrownie cieplne (wykorzystujące węgiel kamienny, węgiel brunatny oraz gaz ziemny), wodne i wiatrowe. Moc zainstalowana w elektrowniach w ramach Krajowego Systemu Elektroenergetycznego (KSE) w ciągu ostatniej dekady systematycznie wzrastała: od ok. 35,3 tys. MW w 2008 r. do blisko 43,3 tys. MW w 2017 r. Zmiany wystąpiły także w strukturze elektrowni. Najbardziej zauważalny jest blisko 8-krotny wzrost mocy elektrowni wiatrowych: z 724,6 MW w 2008 r. do 5858 MW w 2017 r. Szczegółowa analiza struktury i mocy elektrowni w latach 2008 i 2017 została zamieszczona w tabeli 1.

Tabela 1. Moc zainstalowana w elektrowniach [w MW] oraz udział procentowy struktury elektrowni [w \%] w roku 2008 i $2017^{\mathrm{a}}$.

\begin{tabular}{|l|r|r|r|r|r|}
\hline & $\begin{array}{c}\text { Moc w 2008 } \\
{\left[\mathrm{MW}^{*}\right]}\end{array}$ & $\begin{array}{c}\text { Udział } \\
{[\mathrm{w} \%]}\end{array}$ & $\begin{array}{c}\text { Moc w 2017 } \\
{\left[\mathrm{MW}^{*}\right]}\end{array}$ & $\begin{array}{r}\text { Udział } \\
{[\mathrm{w} \%]}\end{array}$ & $\begin{array}{c}\text { Zmiana } \\
{[\mathrm{w} \%]}\end{array}$ \\
\hline Ogółem & 35855 & 100,00 & 43332 & 100,0 & 20,9 \\
\hline $\begin{array}{l}\text { Elektrownie zawodowe } \\
\text { na węglu kamiennym }\end{array}$ & 20433 & 57,00 & 20416 & 47,1 & $-0,1$ \\
\hline $\begin{array}{l}\text { Elektrownie zawodowe } \\
\text { na węglu brunatnym }\end{array}$ & 9030 & 25,20 & 9406 & 21,7 & 4,2 \\
\hline Elektrownie zawodowe gazowe & 769 & 2,10 & 2327 & 5,4 & 202,6 \\
\hline $\begin{array}{l}\text { Elektrownie wiatrowe } \\
\text { i inne odnawialne }\end{array}$ & 863 & 2,40 & 6242 & 14,4 & 623,3 \\
\hline Elektrownie zawodowe wodne & 2209 & 6,20 & 2376 & 5,5 & 7,6 \\
\hline Elektrownie przemysłowe & 2551 & 7,1 & 2565 & 5,9 & 0,5 \\
\hline
\end{tabular}

${ }^{a}$ Do szczegółowej analizy zostały zastosowane dane jedynie z dwóch lat - pierwszego i ostatniego (2008 i 2017) z rozpatrywanego okresu, aby zachować przejrzystość i czytelność tabeli; ${ }^{b}$ Kolumna przedstawia procentową zmianę mocy zainstalowanej w 2017 r. w stosunku do tej z roku 2008; *MW - megawat $=1000 \mathrm{~kW}=1000000 \mathrm{~W}$ - jednostka pomiaru mocy energii elektrycznej.

Źródło: opracowanie własne na podstawie danych Polskich Sieci Elektroenergetycznych [https://www. pse.pl/dane-systemowe/funkcjonowanie-rb/raporty-roczne-z-funkcjonowania-kse-za-rok/raporty-za-rok-2017\#t7_3].

Dane z tabeli 1. wskazują na wzrost o 20,9\% (do 43,3 tys. MW) zainstalowanej mocy ogólnej w ciągu badanego dziesięciolecia. Zauważyć można dominują- 
cą pozycję elektrowni cieplnych, które w 2008 r. posiadały łączny udział 84,3\%, a w 2017 r. ich udział wyniósł 74,2\%, zatem w ciągu dekady udział ich mocy w ogólnej strukturze mocy spadł o 10\%. Wśród elektrowni cieplnych najwyższy wzrost mocy zanotowały elektrownie zawodowe gazowe, których moc wzrosła o 202,6\%, natomiast udział w rocznej strukturze mocy wyniósł 5,4\% w 2017, wobec $2,1 \%$ w 2008 r. Zmianie uległa też struktura mocy pozostałych elektrowni cieplnych: udział elektrowni opartych na węglu kamiennym spadł o 9,9 p.p. $(47,1 \%-57,0 \%)$, a udział elektrowni opartych na węglu brunatnym według tej samej metodologii spadł o 3,5 p.p. Najbardziej imponujący wzrost mocy zanotowała grupa elektrowni wiatrowych i innych odnawialnych (biomasa/biogaz, geotermalne, solarne) - ich moc wzrosła o $5379 \mathrm{MW}$, co daje przyrost o $623,3 \%$. Wzrost ten przełożył się na zwiększenie udziału w strukturze mocy o 12 p.p., do 14,4\% udziału w 2017 r. Moc oraz udział procentowy w strukturze pozostałych grup: elektrowni zawodowych wodnych i elektrowni przemysłowych pozostały na względnie stałym poziomie.

\section{Zużycie energii elektrycznej}

Rynek energii elektrycznej w Polsce nie jest zbilansowany - zawsze występują różnice pomiędzy produkcją energii a jej zużyciem. W tabeli 2. znajdują się dane dotyczące rocznej produkcji i zużycia energii w TWh w Polsce w latach 2008-2017.

Tabela 2. Zużycie oraz produkcja energii elektrycznej [w TWh*] w Polsce w latach 2008-2017

\begin{tabular}{|l|c|c|c|c|c|c|c|c|c|c|}
\hline \multicolumn{1}{|c|}{ Rok } & 2008 & 2009 & 2010 & 2011 & 2012 & 2013 & 2014 & 2015 & 2016 & 2017 \\
\hline Zużycie energii & 155,0 & 148,7 & 154,9 & 157,9 & 157,0 & 157,9 & 158,7 & 161,4 & 164,6 & 168,1 \\
\hline Produkcja energii & 155,5 & 151,7 & 157,7 & 163,5 & 159,9 & 162,5 & 156,6 & 161,7 & 162,6 & 165,8 \\
\hline
\end{tabular}

* TWh - terawatogodzina $=1000 \mathrm{MWh}=1000000 \mathrm{kWh}$ (jednostka pomiaru energii elektrycznej).

Źródło: opracowanie własne na podstawie danych GUS [https://stat.gov.pl/obszary-tematyczne/srodowisko-energia/energia/energia-2017-folder,1,5.html].

Analizując je, można zauważyć wzrost zarówno zużycia, jak i produkcji energii elektrycznej w całym badanym okresie. Oczywiście, dane za kilka lat (np. lata 2009, 2012 lub 2015) ukazują niewielkie spadki wskaźników, jednak całościowy stan wskazuje na wzrosty. Najwyższy spadek, a zarazem najniższe wartości obu omawianych wskaźników miały miejsce w 2009 r., kiedy to zużycie energii spadło o $4,1 \%$, produkcja zaś zmalała o $2,45 \%$. Powodem było wyhamowanie produkcji przemysłowej w reakcji na ogólnoświatowy kryzys z 2008 r., którego skutki w Europie zaczęły się objawiać w 2009 r. W ciągu kolejnych lat analizowane wielkości charakteryzowały się przeważnie wzrostem. Lata, w których występuje przewaga zużycia energii nad jej produkcją, świadczą o imporcie energii netto.

Wskaźnik konsumpcji energii elektrycznej jest jedną z miar rozwoju gospodarki, jednak aby możliwe było porównanie z innymi krajami, należy ten wskaźnik 
podzielić przez liczbę obywateli kraju. Dla Polski omawiana wielkość per capita zamieszczona została w tabeli 3 . W zestawieniu zamieszczone zostały również dane dla Niemiec, czyli „,najsilniejszej” gospodarki w Europie.

Tabela 3. Zużycie energii elektrycznej per capita [w kWh]* w Polsce i Niemczech w latach 2008-2017

\begin{tabular}{|l|l|l|l|l|l|l|l|l|l|l|}
\hline \multicolumn{1}{|c|}{ Rok } & 2008 & 2009 & 2010 & 2011 & 2012 & 2013 & 2014 & 2015 & 2016 & 2017 \\
\hline Polska & 3445 & 3320 & 3519 & 3589 & 3627 & 3655 & 3700 & 3781 & 3856 & 3936 \\
\hline Niemcy & 7156 & 6780 & 7303 & 7202 & 7201 & 7120 & 6871 & 7043 & 6997 & 6987 \\
\hline
\end{tabular}

* Dane przedstawiają średnie roczne zużycie energii elektrycznej w kraju. Wskaźnik został uzyskany poprzez podzielenie całkowitego zużycia energii elektrycznej w danym roku przez liczbę obywateli kraju w analogicznym okresie.

Źródło: opracowanie własne na podstawie danych EMIS [https://www-1emis-1com-1000945e00005. han.bg.umcs.edu.pl].

Dane z tabeli 3. wskazują, że zużycie energii elektrycznej per capita w Polsce we wszystkich badanych okresach było znacznie niższe niż w przypadku Niemiec. Jednakże wart zauważenia jest fakt, że dla Polski rozpatrywany wskaźnik cechuje się ciągłym wzrostem (wyjątek rok 2009), podczas gdy w Niemczech występują znaczne wahania bez wyraźnego kierunku rozwoju.

Oprócz charakterystyki ilościowej ważna jest również jakościowa. W statystyce publicznej grupy konsumentów energii elektrycznej są klasyfikowane jako sektory ekonomiczne. Według klasyfikacji Agencji Rynku Energii SA udostępnianych przez Bank Danych Lokalnych wyróżnić można: sektor przemysłowy, sektor energetyczny, sektor transportowy, gospodarstwa domowe, rolnictwo, pozostałe zużycie.

Tabela 4. Zużycie energii elektrycznej [w TWh] według sektorów ekonomicznych w Polsce w latach 2008-2016*

\begin{tabular}{|l|r|r|r|r|r|r|r|r|r|}
\hline \multicolumn{1}{|c|}{ Rok/Nazwa sektora } & 2008 & 2009 & 2010 & 2011 & 2012 & 2013 & 2014 & 2015 & 2016 \\
\hline Sektor przemysłowy & 44,7 & 40,4 & 42,1 & 44,8 & 45,8 & 47,9 & 48,2 & 49,9 & 52,0 \\
\hline Sektor energetyczny & 24,0 & 23,9 & 26,0 & 25,7 & 25,7 & 26,5 & 25,3 & 26,1 & 25,7 \\
\hline Sektor transportowy & 5,8 & 4,2 & 4,6 & 4,2 & 4,3 & 4,1 & 3,9 & 4,3 & 4,6 \\
\hline Gospodarstwa domowe & 27,1 & 27,5 & 28,6 & 28,3 & 28,3 & 28,4 & 28,1 & 28,3 & 28,9 \\
\hline Rolnictwo & 1,6 & 1,6 & 1,6 & 1,6 & 1,6 & 1,5 & 1,5 & 1,5 & 1,6 \\
\hline Pozostałe zużycie & 40,4 & 39,3 & 41,4 & 43,1 & 42,8 & 41,2 & 43,9 & 43,9 & 46,3 \\
\hline
\end{tabular}

* Dane za rok 2017 nie zostały jeszcze opublikowane.

Źródło: opracowanie własne na podstawie Banku Danych Lokalnych [https://bdl.stat.gov.pl].

Tabela 4. przedstawia roczne zużycie energii elektrycznej w TWh według sektorów ekonomicznych w Polsce w latach 2008-2016. W rozpatrywanym okresie największe zużycie energii charakteryzowało sektor przemysłowy, który w 2016 r. osiągnął konsumpcję na poziomie $52 \mathrm{TWh}$, co jest największą wartością w całym zestawieniu. Kolejne dwa sklasyfikowane sektory to gospodarstwa domowe oraz 
sektor energetyczny. Cechują się one zbliżoną konsumpcją, z niewielką przewagą gospodarstw domowych. Dalej można uplasować sektor transportowy i rolnictwo. Pozostały udział należy przypisać do innych niesklasyfikowanych grup, z których najistotniejszy jest sektor usług. Patrząc całościowo, konsumpcja tej grupy jest drugą co do wielkości i tylko nieznacznie ustępuje sektorowi przemysłowemu. Sumarycznie zużycie energii we wszystkich grupach wymienionych w tabeli 4. wzrosło, z wyjątkiem sektora rolnictwa, który charakteryzował się stałym zapotrzebowaniem na energię w badanym okresie.

Wśród wymienionych sektorów większą uwagę trzeba poświęcić sektorowi gospodarstw domowych. W ostatnim dziesięcioleciu powierzchnia mieszkań zajmowanych przez gospodarstwa domowe w Polsce systematycznie rosła. Mieszkania są większe i coraz lepiej wyposażone. Jednocześnie spada średnia liczba osób je zamieszkujących. Według danych Głównego Urzędu Statystycznego w 2016 r. powierzchnia przeciętnego mieszkania wynosiła $77,2 \mathrm{~m}^{2}$ i składało się ono z 3 pokoi (w 2015 r. było to średnio 76,7 $\mathrm{m}^{2}$ i 2,9 pokoju). Na konsumpcję prądu w gospodarstwach domowych wpływa m.in. miejsce zamieszkania, liczba mieszkańców, sposób ogrzewania, ilość i jakość wyposażenia w sprzęty zasilane elektryczne oraz indywidualne przyzwyczajenia osób. Według raportu najwięcej energii przeznaczane jest na ogrzewanie mieszkania i ogrzewanie wody. Dopiero trzecią pozycją jest konsumpcja energii przez sprzęty AGD i RTV, a kolejną oświetlenie. Wynika to ze zmiany przestarzałych sprzętów na bardziej energooszczędne oraz stosowanie np. żarówek LED [GUS 2017b]. Przeciętne roczne zużycie energii elektrycznej w przeliczeniu na $1 \mathrm{~m}^{2}$ powierzchni mieszkania wynosi $29,35 \mathrm{kWh} / \mathrm{m}^{2}$, co według statystyk przekłada się na roczną konsumpcję w przedziale 1900-2500 kWh dla gospodarstwa domowego $2+2$ (dwoje rodziców i dwoje dzieci), ok. $1000 \mathrm{kWh}$ dla singli oraz 1200-1500 dla rodziny 1+1 [GUS 2017b].

\section{Perspektywy dla sektora energetyki w Polsce}

Energetyka jest jednym z kluczowych sektorów gospodarki. Od jej sytuacji zależy sytuacja całej gospodarki, a zatem ważne jest, aby wszelkie ważne decyzje dotyczące sposobu funkcjonowania sektora energetyki podejmować w sposób przemyślany, uwzględniając wszelkie czynniki na niego wpływające. Z uwagi na strategiczne znaczenie energii dla bezpieczeństwa kraju oraz niedoskonałość niektórych aspektów wolnego rynku Polska stosuje aktywną politykę energetyczną oraz ma określone plany długoterminowe co do jej charakteru w przyszłości. Perspektywy i plany długoterminowe powinny więc uwzględniać [Luchter 2007]:

- Politykę Unii Europejskiej.

- Bezpieczeństwo energetyczne kraju.

- Sytuację oraz trendy w krajowej i światowej gospodarce.

- Specyfikę powiązań gospodarczych, np. stan sektora górnictwa.

- Ochronę klimatu. 
- Koszty ekonomiczne i społeczne inwestycji.

- Postęp technologiczny i stosowanie nowych źródeł energii.

- Zużycie istniejącej infrastruktury.

Aktualnie Polska posiada strategię rozwoju energetyki przedstawioną w dokumencie Polityka energetyczna Polski do roku 2030, a w przygotowaniu znajduje się dokument nakreślający strategię rozwoju energetyki do 2050 r. Ponadto obowiązującymi dokumentami w tej materii są również Strategia bezpieczeństwo energetyczne i środowisko - perspektywa do 2020 r. oraz rozporządzenia Unii Europejskiej, m.in. Czysta energia dla wszystkich Europejczyków [Ministerstwo Energii 2018]. Założenia opisane w dokumentach są w większości ustaleń wspólne i opierają się na następujących założeniach [Ministerstwo Gospodarki 2009a]:

- Poprawa efektywności energetycznej.

- Wzrost bezpieczeństwa dostaw paliw i energii.

- Zdywersyfikowanie struktury wytwarzania energii elektrycznej poprzez zastosowanie energetyki jądrowej.

- Rozwój wykorzystania odnawialnych źródeł energii (zwłaszcza biomasy i energii wiatrowej).

- Rozwój konkurencyjności rynku paliw i energii.

- Zmniejszenie negatywnego oddziaływania energetyki na środowisko.

Poprawa efektywności energetycznej spodziewana jest poprzez budowę nowych bloków energetycznych oraz modernizację już istniejących. Część przestarzałych elektrowni ma być wygaszana, natomiast nowe inwestycje mają spełniać normy UE dotyczące niższej emisji zanieczyszczeń.

Bezpieczeństwo energetyczne zostanie zwiększone poprzez wyższy stopień dywersyfikacji źródeł dostaw surowców. Przede wszystkim dotyczy to dostaw gazu ziemnego i uniezależnienia się od dostaw ze strony Rosji. Poprzez gazoport w Świnoujściu Polska może przyjmować dostawy skroplonego gazu z całego świata. Ponadto planowana jest budowa Baltic Pipe łączącego Polskę z Danią, co umożliwi dostawy gazu z Norwegii. Sukcesywnie zwiększa się krajowe wydobycie gazu oraz trwają intensywne badania nad wydobyciem tzw. gazu łupkowego, którego Polska ma ogromne zasoby [Enerdata 2018]. Planowana jest budowa dwóch elektrowni atomowych (każda o mocy 3000 MW). Pierwsza z nich ma być uruchomiona w 2029 r., druga w 2035 r. Do roku 2020 ma się zakończyć etap wstępny, polegający na wyborze miejsca powstania, zastosowanej technologii, uzyskaniu niezbędnych zezwoleń oraz budowie modelu ekonomicznego współpracy spółek Skarbu Państwa finansujących inwestycję. Po ukończeniu elektrownie mają odpowiadać za ok. 15\% energii wytworzonej w Polsce.

Elektrownie wykorzystujące odnawialne źródła energii (OZE) z roku na rok mają coraz większy udział w rynku energii. Prognozy przewidują, że do $2030 \mathrm{r}$. zwiększy się on do 20\%. Największy udział w tym wzroście przypadnie na elektrownie wiatrowe oraz wykorzystujące biomasę. Inwestycje w OZE są w znacznym stopniu współfinansowane przez środki pochodzące z UE. 
Rozwój konkurencyjności rynku paliw i energii ma na celu usprawnienie rynku oraz uczynienie go bardziej odpornym na niekorzystne warunki zewnętrzne (np. wahania cen surowców na rynkach kapitałowych). Cel ma zostać osiągnięty poprzez pakiet ustaw deregulacyjnych zwiększających zakres konkurencyjnych rynków.

Zmniejszenie oddziaływania energetyki na środowisko ma odbywać się m.in. poprzez stopniowe dostosowanie do wymagań UE zawartych w przepisach o ograniczeniu emisji szkodliwych gazów $\left(\mathrm{CO}_{2}, \mathrm{SO}_{2}\right)$ oraz pyłów zawieszonych do atmosfery. Substancje te w znacznym stopniu są uwalniane przy spalaniu węgla. Polska energetyka jest oparta na paliwach kopalnych i pomimo ich spadającego udziału w najbliższych latach sytuacja się nie zmieni. Dlatego też Polska może mieć trudności z osiągnięciem zakładanych limitów do roku 2030.

Zmiany w sektorze energetyki będą w znacznym stopniu wpływać na zużycie energii elektrycznej. Według analiz konsumpcja energii elektrycznej do 2030 r. będzie wzrastać, co jest cechą ,nadrabiania zaległości” w rozwoju i jest to zjawisko charakterystyczne dla gospodarek, które przeszły transformacje ustrojowe po $1989 \mathrm{r}$. W 2030 r. prognozowane jest roczne zużycie energii na poziomie $240 \mathrm{TWh}$ [Ministerstwo Gospodarki 2009b]. Przewidywane są również zmiany w strukturze zużycia. Zmaleć ma udział sektora przemysłu (ze względu na modernizację i związaną z nią niższą energochłonnością zakładów przemysłowych), wyższą konsumpcję energii ma uzyskać najdynamiczniej rozwijający się sektor usług ${ }^{2}$ oraz gospodarstwa domowe (głównie przez wzrost liczby samochodów elektrycznych oraz zwiększenie liczby urządzeń współpracujących z sobą - koncepcja smart domów) [Ministerstwo Gospodarki 2009b].

Według prognoz realne ceny (w odniesieniu do inflacji) zużywanej energii powinny utrzymać się na stałym poziomie. Koszty limitów emisji $\mathrm{CO}_{2}$ oraz konieczność finansowania rozpoczętych i planowanych inwestycji będzie równoważony przez wyższą efektywność systemu energetycznego oraz zdywersyfikowanie źródeł energii (niższe koszty uzyskiwania energii z elektrowni atomowych i wykorzystujących OZE) [Ministerstwo Energii 2018].

\section{Zakończenie}

Rynek energii elektrycznej w Polsce podlega wielu istotnym modyfikacjom, które dobrze widoczne były w latach 2008-2017. Szybkie tempo realizowanych i planowanych zmian jest efektem polityki Unii Europejskiej, nakreślającej kierunki rozwoju energetyki w krajach członkowskich. W badanym okresie można było zaobserwować sukcesywny wzrost mocy elektrowni oraz głębokie zmiany w ich strukturze. Pomimo wciąż dominującej pozycji elektrowni opartych na węglu kamiennym i brunatnym, ich udział w rynku z roku na rok maleje. Na znaczeniu zyskują natomiast elektrownie oparte na odnawialnych źródłach energii oraz elektrownie gazo-

2 Sektor usług jest ujęty w grupie „Pozostałe zużycie” (por. tab. 4). 
we. Według prognoz tendencja ta utrzyma się również w przyszłości. Ponadto zostały podjęte działania zmierzające do budowy i wykorzystania elektrowni atomowych. Mają one zdywersyfikować rynek energii, czyniąc go mniej szkodliwym dla środowiska.

Produkcja oraz zużycie energii elektrycznej są silnie z sobą związane. W latach 2008-2017 można było obserwować wzrost zużycia prądu przypadającego na 1 mieszkańca, co jest jednym ze wskaźników rozwoju gospodarczego kraju. Konsumpcja wzrastała zwłaszcza w sektorze przemysłu i usług oraz w gospodarstwach domowych.

Polityka energetyczna Polski jest prowadzona z uwzględnieniem wielu determinantów związanych zarówno z polityką krajową, jak i międzynarodową. Rząd oraz Unia Europejska nakreślają kierunki realizacji strategicznych celów, które w przyszłości mają doprowadzić sektor energetyczny do niższej emisyjności, nastawić na wykorzystanie zdywersyfikowanych źródeł oraz zapewnić wyższe bezpieczeństwo energetyczne. Szczegółowe działania zmierzające do osiągnięcia celów są często modyfikowane w zależności od „klimatu politycznego”, jednak zapisy ogólne są ciągle konsekwentnie realizowane. W celu osiągnięcia zamierzonego stanu potrzebne są jeszcze liczne prace inwestycyjne i ustawodawcze.

\section{Literatura}

Bank Danych Lokalnych, https://bdl.stat.gov.pl (21.04.2018).

EMIS Intelligence, https://www-1emis-1 com-1000945e00005.han.bg.umcs.edu.pl (20.04.2018).

Enerad.pl, https://enerad.p1/rynek-energii/dodatkowo/osd-dystrybutorzy/ (18.04.2018).

Enerdata, 2018, Country Energy Report - Poland 2018, London, United Kingdom, dostęp poprzez licencjonowane bazy danych EMIS, https://www-1emis-1 com-1000945e00005.han.bg.umcs.edu. pl (27.04.2018).

GUS, 2017a, Sprawozdanie dotyczace energii w Polsce, Główny Urząd Statystyczny, https://stat.gov. $\mathrm{pl}(20.04 .2018)$.

GUS, 2017b, Budżety gospodarstw domowych w 2016 r., Główny Urząd Statystyczny, Warszawa.

https://stat.gov.pl/obszary-tematyczne/srodowisko-energia/energia/energia-2017-folder, 1,5.html (25.04.2018).

Internacional Energy Agency, 2014, World Energy Outlook 2014, Paris, France.

Luchter L., 2007, Przemiany strukturalne i przestrzenne sektora elektroenergetyki w Polsce w latach 1990-2005, [w:] J. Lach, M. Borowiec, T. Rachwał (red.), Procesy transformacji społeczno-ekonomicznych i przyrodniczych struktur przestrzennych, Wydawnictwo Naukowe Akademii Pedagogicznej, Kraków.

Mielczarski W., 2000, Rynki energii elektrycznej. Wybrane aspekty techniczne i ekonomiczne, Wydawnictwo Agencja Rynku Energii SA i Energoprojekt-Consulting SA, Warszawa.

Ministerstwo Energii, https://www.me.gov.pl/Energetyka/Polityka+energetyczna (25.04.2018).

Ministerstwo Gospodarki, 2009a, Polityka energetyczna Polski do roku 2030, http://www.me.gov.pl/ files/upload/8134/Polityka\%20energetyczna\%20ost.pdf (25.04.2018). 
Ministerstwo Gospodarki, 2009b, Prognoza zapotrzebowania na paliwo i energię do 2030 roku, http://www.me.gov.pl/files/upload/8134/Prognoza\%20zapotrzebowania\%20na\%20paliwa\%20 i\%20energie-ost.pdf.

Polskie Sieci Elektroenergetyczne, https://www.pse.pl/dane-systemowe/funkcjonowanie-rb/raporty-roczne-z-funkcjonowania-kse-za-rok/raporty-za-rok-2017\#t7_3 (18.04.2018).

Ustawa z 10 kwietnia 1997 r. Prawo energetyczne, Dz.U. 2017, poz. 220. 